\title{
Congress stirs non-proliferation row
}

\section{Testimony}

\section{on Iraq raid}

\section{backfires}

A serious row affecting the future of the Non-Proliferation Treaty has broken out between the United States government and the International Atomic Energy Agency in Vienna. At issue is the appearance before two congressional committees in the past two weeks of a defector from the agency's safeguards inspectorate, Dr Roger Richter (33). At a meeting of the board of the agency in Vienna this week, Dr Sigvard Eklund, director-general of the agency, said that Dr Richter's evidence to the Senate and House committees on Foreign Relations (on 18 June and 1 July respectively) had involved the disclosure of confidential information in breach of his contract of employment, and that the agency was taking legal advice.

Dr Richter's appearances have been dramatic, to say the least. According to $\mathrm{Dr}$ Eklund's statement on Monday, Dr Richter last showed up for work in Vienna on 15 June. The following day, Senator Alan Cranston, chairman of the Senate committee on Foreign Relations, announced in Washington that Dr Richter, having resigned for the occasion, would be giving evidence three days later. $\mathrm{Dr}$ Richter's resignation was received by telex in Vienna on 18 June, according to $\mathrm{Dr}$ Eklund; it was not, however, accepted, but Dr Richter was instead fired.

Dr Eklund in his statement said that Dr Richter had worked for the agency since February 1978, and that he had been assigned to the section of the agency concerned with supervising safeguards in the "south and south-east" sections of the agency's territory, including both Iraq and Israel, in March 1979. Dr Richter's evidence to the congressional committees consisted most conspicuously of the assertion that the agency's safeguards were not adequate to detect violations of the Non-Proliferation Treaty by Iraq.

Dr Richter was dissuaded by Senator Cranston from quoting from a letter he had written a year ago to the US State Department, in which he had alleged that "the IAEA safeguards are totally incapable of detecting the production of plutonium in large scale materials-test reactors. . ." such as that destroyed by the Iraeli raid on Tamuz on 7 June.

One of the reasons why the agency has taken umbrage is that neither house of Congress has taken its denials seriously. On Monday, Dr Eklund told his board that the authorities in Iraq had been approached immediately after the Israeli raid on Tamuz and visited the site on 18 June. They were unable to visit the main reactor because of the extent to which it had been damaged (and the insistence of the Iraqi authorities on a personal accident indemnity). The associated research reactor and the stockpile of enriched uranium was however inspected and found in order.

For the agency, the incident obviously raises serious questions about the fiduciary responsibilities of its safeguards inspectors. One requirement of the NonProliferation Treaty is that information gathered by inspection teams should be kept confidential. The fact that a defecting inspector should have told all to Congress on the day of his formal resignation is a serious blow to the system.

In the United States, Dr Richter's evidence to the Senate and the House has had an equally profound effect, and may impede the Administration's declared intention of liberalizing restrictions (made necessary by the Carter Anti-Proliferation Act) on the export of nuclear technology. The nuclear industry has been especially critical of the act's requirements that

\section{British universities transformed by budget}

A major reshaping of the British university system was decreed last week, when the University Grants Committee sent letters to each of the 51 universities in Britain giving details of their recurrent grants for the next three academic years. But the full implications of what the committee has decided will not be clear until the details have been analysed by the Committee of Vice-Chancellors and Principals, to which the universities have separately (but in confidence) provided copies of the letters they have received from the committee.

Two features of the new pattern are however apparent. By the beginning of the academic year 1984-85, the total number of students from the United Kingdom and elsewhere in the European Community is to be no greater than 249,000 , five per cent less than last year (the base year for all the committee's calculations) and 7.5 per cent less than in the current academic year. And the total recurrent grant for the universities, paid on the recommendation of the University Grants Committee, will fall from $£ 972$ million in the current year to £808 million in 1983-84.

As well as publishing a general statement of what it was about, the committee last week sent individual letters to universities including what is called "advice" about the teaching activities that should be continued (and sometimes strengthened) but also, in many cases, abandoned. Most recommendations of this kind, which only the bravest universities will ignore, concern the arts or social sciences. But some universities have also been "invited" to recipient nations, even those that had signed the treaty, should go further than merely accept the Vienna safeguards before becoming eligible.

Part of the reason why the Carter Act has been controversial among potential recipients of United States' nuclear technology is that one condition for their signature of the treaty, in the early 1970s, was the promise that nuclear powers would assist with the development of peaceful nuclear technology.

Opinion is divided in Washington about the strength of Dr Richter's testimony.

In Congress, however, Senator Charles Percy, chairman of the Senate Foreign Relations Committee, says he has been shaken by Richter's evidence.

The chief casualty is likely to be the Administration's determination to reform the anti-proliferation policy it inherited in February. Even President Reagan startled the nuclear industry when he acknowledged at last week's press conference that signature of the NonProliferation Treaty did not necessarily imply compliance.

abandon teaching their brand of biology .

The University Grants Committee (which has no formal mechanism for dealing with enquiries from the press) is not prepared to say how its decisions about individual universities have been arrived at. It seems, however, to have sought to preserve excellence and minority areas of study and to encourage what is known as "thrift" while maintaining regional balances. Unit costs appear to have been influential in the case of the University of Bath which, while boasting of a diversified programme of studies linked broadly (and sometimes loosely) with industry, also boasts of the lowest costs per student in Great Britain, and has been the most generously treated university of all - its income is cut by merely 7 per cent

It is also known that the committee, in making specific recommendations to the Department of Education and Science for grants to individual universities, took advice about the performance of universities in competition for research grants from the research councils. One vice-chancellor, at least, is glad to think that his university's relative immunity from impending frugality stems from his academics' success in raising more than $£ 3$ million a year by way of grants.

Vice-chancellors at the newer technological universities most severely affected by the cuts complain, however, that in its calculations of external research support the grants committee has paid too little attention to research support provided by industrial companies as distinct from research councils. They also 